\title{
最近の歯学
}

\section{2. 補綴}

咬合小面について

上下顎歯列の対向関係，接触関係は歯科学の臨床各分 野に抢いて診断, 治療, 再現の上から基本的でかつ共通 の問題である。一方，咬合小面（咬耗面）は上下顎歯列 間の接触および咀嚼運動を解明する際の歯牙要素として 重視されている。

尾花(1957) は咬合小面の傾斜角度を二つの角度（傾斜 角，方位角）にわけ立体的に表わし，石原の考案した光 学的装置を用いて測定を行っている。その結果, 前頭断 に扔ける作業側咬合小面の断面傾斜角度は犬歯において 最大值を示し, 臼歯部に㧍いて角度が減少し, 平衡側咬 合小面では第 1 小臼歯より増加し第 2 大臼歯において最 大值を示し，作業側，平衡側ともに咬合小面は規則性を もって配置されていることを明かにした。

藍(1962) は咀嚼運動路と咬合小面の傾斜角度を前頭面 で比較検対し，両者にある程度の相関のあることを明か にしている。

しかし，咬合小面が上下顎歯牙の接触状態に関係づけ て，その形と成り立ちが明らかにされていないために咬 合小面をいかに解釈するかは明らかでない。そこで著者 は臨床的に正常と思われる被験者を使用して, 歯列模型 上に括ける咬合小面の明示を行い, $50 \mu$ 以内の歯牙の接 触状態を正確に知る方法としてシリコーン・ブラック法 を，歯牙 (咬合小面) と接触の関係を求める方法として 歯列咬合平面投影図の両者を考案し，（補緅誌，14 巻 1 号) これを追求した。

これらの観察から咬合小面は他の歯面の連続する局面 とは異なり周波条とも明らかに区別できる clear-cut な 境界をもつ面で被験者の全例, すべての歯牙において出 現していること，そして，すべての接触は咬合小面内に おいて発現することが明らかになった。

現在，咬合小面の成因に関して，対合歯の接触のみに よるもの，食物等の介在物のみによるもの，接触と介在 物の両者によるものの 3 者の分類が考えられる。仮りに 介在物のみに原因を求めると当然, 咬合小面の境界法鈍 となり歯牙全体に咬合小面が観察され，著者の確認した 咬合小面以外において接触は起るべきである。さらに介 在物の影響をうけないと考えられる隣接面接触点部にお いても同様の clear-cut 小面が観察されることからもこ れのみを原因とすることは否定される。

図 1 は咬頭嵌合位における上下係舌面の 1 例を示す。 矢印の上頒犬歯舌側の咬合小面は現在のいかなる顎位の 接触を想定しても理解できないものであるが，この咬合 小面は萠出後の下額犬歯咬頭とその形が類似しておう,
第 2 歯科補緅学教室 中尾勝彦

上下顎犬歯が萠出後互に咬頭が接触し咬耗により咬頭頂 は失なわれ，その軌跡が対向歯にみられる。

図 2 は下顎第 1 大臼歯近心煩側咬頭を示すが，この咬 頭の咬合小面は他の咬頭に出現するものとは異なり, 咬 頭の内外斜面, 近心斜面にかけて鈍円状の移行を示し, 半数例に象乒質の露出があり咬耗が進行している。この 咬合小面の成因については乳歯列から永久歯列へと移行 する際，すなわち第 1 大臼歯が萠出後，上晾第 2 乳白歯 と接触し, その後に上顎第 1 大臼歯と接触関係を確立す るまでの推移を示すと考えられる。

以上のことから咬合小面の成因には現時点の接触ばか りでなく歯牙の萠出から, 移動, 生理的動摇などの動的 軌跡をも含んでいるものと云えよう。

天然歯列の咬合面形態を明らかにする上で咬合小面の 存在は久せないものであり, 今後さらに詳細な検討が望 まれる。

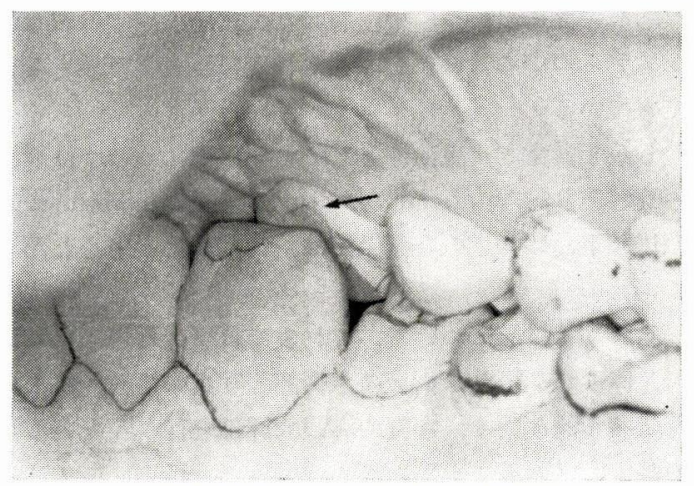

図 1 咬頭嵌合位に㧍ける上擷犬歯舌面の咬合 小面を示す。

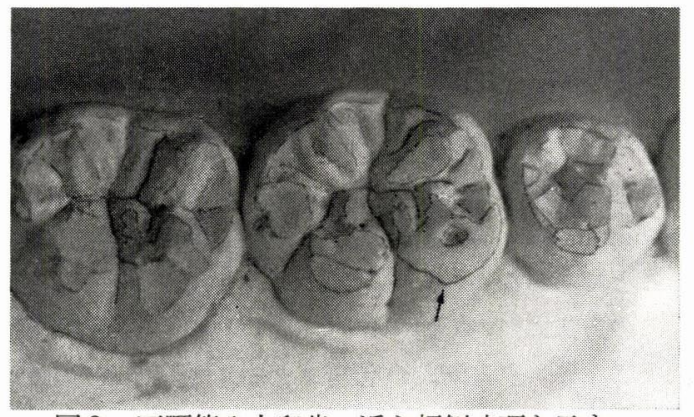

図2 下顎第 1 大臼歯，近心煩側咬頭を示す。 